\title{
THE ASSOCIATION OF OXYGEN-BEARING MINERALS OF CHALCOPHILE ELEMENTS IN THE OROGENETIC ZONE RELATED TO THE "MIXED SERIES" COMPLEX NEAR NEŽILOVO, REPUBLIC OF MACEDONIA *
}

\author{
Nikita V. Chukanov ${ }^{1}$, Simeon Jančev ${ }^{2}$, Igor V. Pekov ${ }^{3}$ \\ ${ }^{1}$ Institute of Problems of Chemical Physics, Russian Academy of Sciences, Chernogolovka, \\ Moscow Region, 142432 Russia \\ ${ }^{2}$ Faculty of Technology and Metallurgy, Ss. Cyril and Methodius University, Ruger Bošković 16, \\ 1000 Skopje, Republic of Macedonia \\ ${ }^{3}$ Faculty of Geology, Moscow State University, Vorobievy Gory, 119991 Moscow, Russia \\ *chukanov@icp.ac.ru
}

\begin{abstract}
New data are obtained for minerals from metasomatic rocks of the orogenetic zone related to the "Mixed series" metamorphic complex situated in the Pelagonian massif near the Nežilovo village, about $40 \mathrm{~km} \mathrm{SW}$ of Veles, Republic of Macedonia. A specific feature of these rocks is the concentration of chalcophile elements ( $\mathrm{S}, \mathrm{As}, \mathrm{Sb}, \mathrm{Zn}, \mathrm{Pb}$ ) mainly in the form of oxides and oxysalts, whereas sulfides and sulfosalts are present only in trace amounts. Rock-forming and accessory minerals have been characterized by electron microscopy, electron microprobe analyses and in part by X-ray diffraction and IR spectroscopic data. Some of described minerals (Sb-rich analogue of zincohögbomite-2N6S, hydroxyplumbobetafite, $\mathrm{Fe}^{3+}$-analogue of coronadite) are potentially new mineral species. Some genetic aspects of the formation of oxidized $\mathrm{As}-\mathrm{Sb}-\mathrm{Zn}-\mathrm{Pb}$-rich rocks are discussed.
\end{abstract}

Keywords: chalcophile elements; minerals; "Mixed series"; Nežilovo; Pelagonian massif

\author{
АСОЦИЈАЦИЈА НА МИНЕРАЛИ ОД ХАЛКОФИЛНИ ЕЛЕМЕНТИ \\ ШТО СОДРЖАТ КИСЛОРОД ВО ОРОГЕНЕТСКАТА ЗОНА ОД КОМПЛЕКСОТ \\ “МЕШАНИ СЕРИИ” БЛИЗУ НЕЖИЛОВО, РЕПУБЛИКА МАКЕДОНИЈА
}

\begin{abstract}
Добиени се нови податоци за минералите во метасоматските карпи на орогенетската зона од метаморфниот комплекс „мешана серија” во пелагонискиот масив близу селото Нежилово, околу 40 км југозападно од Велес, Република Македонија. Специфична карактеристика на овие карпи е концентрацијата на халкофилните елементи ( $\mathrm{S}, \mathrm{As}, \mathrm{Sb}, \mathrm{Zn}, \mathrm{Pb})$, кои се јавуваат главно во форма на оксиди и оксисоли, додека сулфидите и сулфосолите се присутни само во траги. Минералите од кои се формирани карпите и придружните минерали се карактеризирани со помош на електронска микроскопија, рендгенска микроанализа и делумно со рендгенска дифракција и со инфрацрвена спектроскопија. Некои од опишаните минерали (збогатен со $\mathrm{Sb}$ аналог на цинкохогбомит-2N6S, хидроксиплумбобетафит, $\mathrm{Fe}^{3+}$-аналог на коронадит) се потенцијално нови минерални примероци. Дискутирани се некои генетски аспекти на формирање оксидирани карпи збогатени co As-Sb-Zn-Pb.
\end{abstract}

Клучни зборови: халкофилни елементи; минерали; „мешана серија”; Нежилово; пелагониски масив

\footnotetext{
- Dedicated to Academician Gligor Jovanovski on the occasion of his $70^{\text {th }}$ birthday.
} 


\section{INTRODUCTION}

The famous "Mixed series" metamorphic complex situated in the Pelagonian massif near the Nežilovo village, about $40 \mathrm{~km} \mathrm{SW}$ of Veles, Republic of Macedonia, is a metamorphosed volcanosedimentary formation composed mainly of albite augen gneisses and meta-rhyolites around which there are lenses of dolomitic marbles metasomatically replaced by very unusual and complex mineral assemblages $[1,2]$. In the footwall of the mentioned dolomitic marbles and barite schists at the Kalugeri Hill, peculiar quartz-cymrite and cymrite-quartz schists are outcropped [3, 4]. Along with cymrite, these rocks contain other Ba-bearing silicates (hyalophane and sanbornite) as accessories.

The metasomatic rocks forming exo-contact aureoles around the high alkaline body of the metarhyolites are characterized by variable contents of the main rock-forming minerals (barite, dolomite, quartz, $\mathrm{Zn}$-rich phlogopite, Zn-bearing aegirine-augite, Znrich alkaline amphiboles, spessartine, hematite, etc.). Specific accessory minerals belonging to this assemblage are gahnite, franklinite, nežilovite, Zn-bearing braunite, zincohögbomite and its Sb-rich variety (or analogue), Zn-rich rinmanite, tilasite, hedyphane, epidote-( $\mathrm{Pb})$, piemontite-( $\mathrm{Pb})$, etc. [3-17]. Nežilovo is the type locality of nežilovite, piemontite- $(\mathrm{Pb})$ and zincohögbomite-2N6S.

The mineral associations of these metasomatic rocks are very complex. This shows crystallization within a wide temperature range, starting from the pneumatolytic to the lowest-temperature hydrothermal stages, at high Eh values. One of the most interesting specific features of these metasomatic rocks is the high concentration of several typical chalcophile elements $(\mathrm{S}, \mathrm{As}, \mathrm{Sb}, \mathrm{Zn}, \mathrm{Pb})$ forming mainly oxygen-bearing minerals (oxides and oxysalts) among which barite is the major concentrator of sulfur. Sulfide minerals (sphalerite, galena, pyrite and chalcocite) are present there only in trace amounts. Additionally, metacinnabar was detected as a very rare accessory mineral in the fine-grained quartz-barite schists.

In this paper we present new mineralogical data for metasomatic rocks from the orogenetic zone related to the "Mixed series" of Nežilovo.

\section{ANALYTICAL TECHNIQUES}

The EDS-mode electron microprobe analyses, including imaging of the objects in the secondary and backscattered electron (BSE) modes and X-ray microanalysis were performed with two analytical suites, (1) a digital scanning electron microscope Tescan VEGA-II XMU with energydispersive spectrometer (EDS) INCA Energy 450, and (2) a digital scanning electron microscope CamScan MV2300 (VEGA TS 5130MM) with EDS INCA Energy 350. Both electron microscopes are equipped by detectors of secondary and back-scattered electrons on YAG plus an energydispersive X-ray microanalyzer with a semiconducting Link INCA Energy Si (Li) detector. In both cases calculations of results of the X-ray microanalysis were carried out by means of a INCA Energy 300 software package. The analyses were carried out at an accelerating voltage of $20 \mathrm{kV}$. Current of absorbed electrons on a reference sample of cobalt was 510-520 pA, and on the studied polished samples ranged from 150 to $400 \mathrm{pA}$ (depending on a micro-relief, structure and composition of samples). The size of an electron beam on the sample surface varied in the range $157-180 \mathrm{~nm}$ in the analytical mode and up to $60 \mathrm{~nm}$ in the scanning mode. The excitation zone reached 4-5 $\mu \mathrm{m}$. The sample-to-detector distance was $25 \mathrm{~mm}$. BSE imaging was carried out with magnifications from 10 to 2500 .

For powder IR absorption spectroscopy, hand-picked grains were grounded in an agate mortar, mixed with anhydrous $\mathrm{KBr}$, pelletized, and analyzed using ALPHA FTIR spectrometer (Bruker Optics) in the range of wavenumbers from 360 to $3800 \mathrm{~cm}^{-1}$, with the resolution of $4 \mathrm{~cm}^{-1}$ and the number of scans of 16 . The IR spectrum of a pure $\mathrm{KBr}$ disk was subtracted from the overall spectrum.

Powder X-ray diffraction studies of minerals were carried out on a Stoe IPDS II single-crystal diffractometer equipped with an image plate detector using the Gandolfi method (MoKa radiation) and on a Rigaku Miniflex II powder diffractometer $(\mathrm{Cu} K \alpha$ radiation).

\section{MINERALS}

\subsection{Silicates}

The main rock-forming silicate minerals in metasomatites of the Nežilovo orogenetic zone are amphiboles and trioctahedral mica (phlogopite). Their specific feature is an unusually high content of zinc (up to $\sim 10 \mathrm{wt} . \% \mathrm{ZnO}$ in amphiboles and up to $\sim 8$ wt. $\% \mathrm{ZnO}$ in micas).

$\mathrm{Zn}$-rich richterite and amphiboles belonging to the magnesioriebeckite-richterite solidsolution series form yellow, brown or blue-green anhedral grains and split prismatic crystals, as well as their random aggregates embedded in a metasomatic rock (Fig. 1). These minerals crystallized as 
Table 1

Representative compositional data for Zn-bearing rock-forming silicate minerals from the Nežilovo orogenetic zone

\begin{tabular}{|c|c|c|c|c|c|c|c|}
\hline Mineral $\rightarrow$ & $\begin{array}{l}\text { Magnesio- } \\
\text { riebeckite }\end{array}$ & $\begin{array}{l}\text { Magnesio- } \\
\text { riebeckite }\end{array}$ & Richterite & Phlogopite & Phlogopite $^{1}$ & $\begin{array}{l}\text { Aegirine- } \\
\text { augite }\end{array}$ & Spessartine \\
\hline \multirow[t]{2}{*}{ Constituent } & \multicolumn{7}{|c|}{ Wt.\% } \\
\hline & 1 & 2 & 3 & 4 & 5 & 6 & 7 \\
\hline $\mathrm{Na}_{2} \mathrm{O}$ & 7.38 & 6.95 & 7.13 & bdl & bdl & 7.70 & bdl \\
\hline $\mathrm{K}_{2} \mathrm{O}$ & $\mathrm{bdl}^{2}$ & bdl & bdl & 10.72 & 10.12 & bdl & bdl \\
\hline $\mathrm{CaO}$ & 2.37 & 1.10 & 3.40 & bdl & bdl & 1.61 & 6.41 \\
\hline $\mathrm{MgO}$ & 13.45 & 11.51 & 12.07 & 22.15 & 21.03 & 11.36 & 0.44 \\
\hline $\mathrm{MnO}$ & 0.40 & bdl & 1.92 & 1.81 & 1.79 & bdl & 33.29 \\
\hline $\mathrm{FeO}^{3}$ & - & - & 8.67 & 1.54 & 1.06 & bdl & 4.08 \\
\hline $\mathrm{ZnO}$ & 4.71 & 7.70 & 9.34 & 4.94 & 7.30 & 8.03 & 0.63 \\
\hline $\mathrm{Al}_{2} \mathrm{O}_{3}$ & 4.70 & 4.02 & 1.65 & 12.27 & 12.05 & 2.01 & 18.82 \\
\hline $\mathrm{Fe}_{2} \mathrm{O}_{3}{ }^{3}$ & 10.92 & 10.92 & - & bdl & bdl & 13.62 & - \\
\hline $\mathrm{TiO}_{2}$ & bdl & bdl & bdl & bdl & 0.47 & bdl & bdl \\
\hline $\mathrm{SiO}_{2}$ & 54.29 & 55.98 & 54.71 & 41.80 & 39.81 & 55.12 & 36.46 \\
\hline $\mathrm{F}$ & bdl & bdl & bdl & 1.62 & 1.81 & bdl & bdl \\
\hline$-\mathrm{O}=\mathrm{F}_{2}$ & - & - & - & -0.68 & -0.76 & - & - \\
\hline Total & 98.22 & 98.18 & 98.89 & 96.17 & 95.45 & 99.45 & 100.13 \\
\hline \multicolumn{8}{|c|}{ Formula coefficients } \\
\hline $\mathrm{Na}$ & 2.02 & 2.01 & 1.99 & - & - & 0.56 & - \\
\hline $\mathrm{K}$ & - & - & - & 1.00 & 0.96 & - & - \\
\hline $\mathrm{Ca}$ & 0.36 & 0.17 & 0.52 & - & - & 0.06 & 0.56 \\
\hline $\mathrm{Mg}$ & 2.83 & 2.43 & 2.59 & 2.41 & 2.33 & 0.63 & 0.05 \\
\hline $\mathrm{Mn}$ & - & - & 0.23 & 0.11 & 0.11 & - & 2.29 \\
\hline $\mathrm{Fe}^{2+}$ & - & - & 1.03 & 0.10 & 0.07 & - & 0.28 \\
\hline $\mathrm{Zn}$ & 0.50 & 0.80 & 0.99 & 0.27 & 0.40 & 0.22 & 0.04 \\
\hline $\mathrm{Al}$ & 0.79 & 0.61 & 0.28 & 1.06 & 1.06 & 0.09 & 1.81 \\
\hline $\mathrm{Fe}^{3+}$ & 1.16 & 1.23 & - & - & - & 0.38 & - \\
\hline $\mathrm{Ti}$ & - & - & - & - & 0.03 & - & - \\
\hline $\mathrm{Si}$ & 7.68 & 7.93 & 7.87 & 3.05 & 2.96 & 2.06 & 2.97 \\
\hline $\mathrm{F}$ & - & - & - & 0.37 & 0.42 & - & - \\
\hline $\begin{array}{l}\text { Basis of } \\
\text { calculation }\end{array}$ & $\begin{array}{c}13 \text { cations } \\
\text { except } \mathrm{Na} \\
\text { and } \mathrm{Ca}\end{array}$ & $\begin{array}{c}13 \text { cations } \\
\text { except } \mathrm{Na} \text { and } \\
\mathrm{Ca}\end{array}$ & $\begin{array}{c}13 \text { cations } \\
\text { except } \mathrm{Na} \\
\text { and } \mathrm{Ca} \\
\end{array}$ & $\begin{array}{l}7 \text { cations ex- } \\
\text { cept } \mathrm{K}\end{array}$ & $\begin{array}{l}7 \text { cations } \\
\text { except K }\end{array}$ & 4 cations & 8 cations \\
\hline
\end{tabular}

Note: ${ }^{1}$ Additionally this sample contains 0.77 wt. $\% \mathrm{CuO}$ corresponding to 0.04 apfu $\mathrm{Cu}$.

${ }^{2}$ Here and thereafter the mark "bdl" means that the content of corresponding component is below its detection limit.

${ }^{3} \mathrm{The}$ valency of $\mathrm{Fe}$ is accepted according to theoretical formulae (except aegirine-augite that contains both $\mathrm{Fe}^{2+}$ and $\mathrm{Fe}^{3+}$ ).

a result of a high temperature postmagmatic process, after the crystallization of gahnite, franklinite, and Zn-rich pyroxenes. Typical chemical compositions of the amphiboles are given in Table 1 (analyses 1 to 3$)$.

A typical IR spectrum of $\mathrm{Zn}$-rich magnesioriebeckite (Fig. 2) is similar to that of $\mathrm{Zn}$-free magnesioriebeckite [18], but is characterized by relatively broad and poor-resolved bands which indicates a disordered distribution of cations over structural sites. The bands at 3651 and $3639 \mathrm{~cm}^{-1}$ correspond to $\mathrm{OH}$ groups in different coordinations (presumably, $\mathrm{MgMgMg}$ and $\mathrm{MgMgZn}$ respectively).

$\mathrm{Zn}$-rich amphiboles are rare, but not unique. In particular, magnesioriebeckite with $\mathrm{ZnO}$ up to 7.8 wt. $\%$, tremolite with $\mathrm{ZnO}$ up to 4.3 wt. \%, actinolite with $\mathrm{ZnO}$ up to $9.0 \mathrm{wt} . \%$ and $\mathrm{Mn}$-analogue of cummingtonite with $\mathrm{ZnO}$ up to 10.8 wt.\% have been identified in Zn-enriched metasomatic rocks from Franklin, New Jersey, USA [19]; arfvedsonite from alkali granite of the Puklen complex, Greenland, contains up to $4.7 \mathrm{wt} . \% \mathrm{ZnO}$ [20].

Zn-bearing phlogopite (Table 1, analyses 4 and 5) typically occurs as brown split tabular grains. The content of $\mathrm{ZnO}$ is no more than 8 wt.\%; Zn-dominant trioctahedral mica (hendricksite) was not found in metasomatic rocks investigated in this work.

$\mathrm{Zn}$-rich pyroxene is present as corroded acicular crystals in carbonatized zones as relics of the earliest metasomatic stages [10]. Associated minerals are $\mathrm{Sb}$-rich zincohögbomite, Sb-bearing franklinite, $\mathrm{Zn}$-rich richterite, $\mathrm{Zn}$-rich phlogopite, as well as typical hydrothermal minerals (dolomite, 
quartz, albite, barite, tilasite, etc.). The composition of Zn-rich pyroxene corresponds to aegirineaugite (Table 1, analysis 6).

Garnet, unlike aegirine-augite, amphiboles and phlogopite, has a rather low capacity to concentrate $\mathrm{Zn}$. As a rule, the contents of $\mathrm{ZnO}$ in spessartine from the association with $\mathrm{Zn}$-bearing oxide minerals (gahnite, zincohögbomite, almeidaite) is below 1 wt.\% (see analysis 7 in Table 1).

The members of the isomorphous series piemontite-(Pb) - epidote-(Pb) and piemontite(Pb) - Pb-bearing piemontite are the main silicates concentrating lead in the Nežilovo orogenetic zone. These minerals were described by us in detail earlier $[16,17]$.

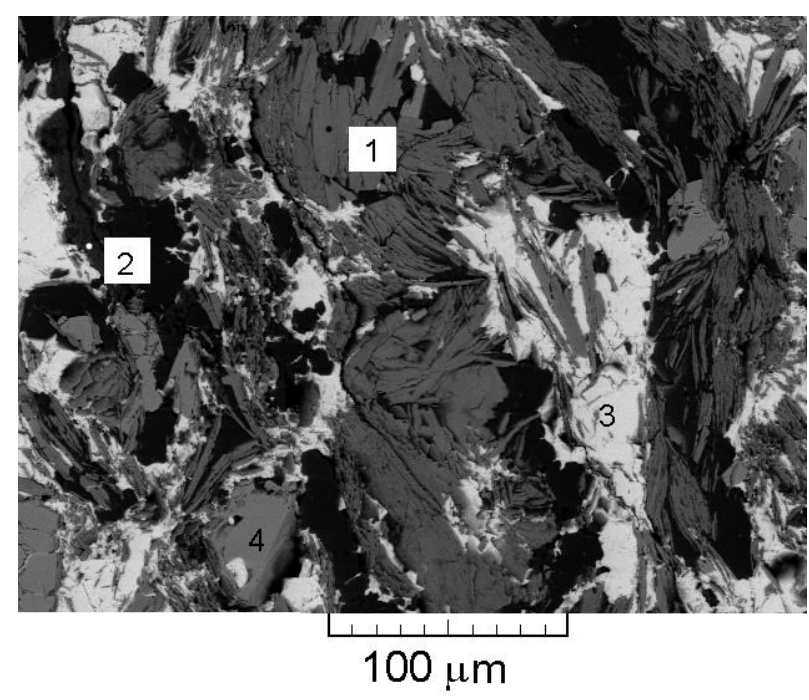

Fig. 1. Aggregates of Sb-bearing zincohögbomite (1), Zn-bearing amphibole (2), barite (3) and hematite (4). Polished section. BSE image.

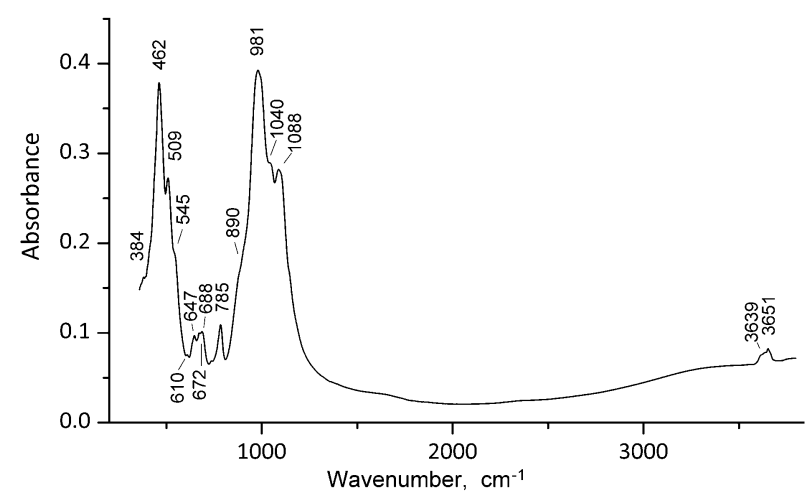

Fig. 2. IR spectrum of $\mathrm{Zn}$-rich magnesioriebeckite.

\subsection{Oxides}

Oxides are the most abundant and the most diverse accessory minerals in rocks of the Nežilovo orogenetic zone and significant concentrators of chalcophile elements, mainly $\mathrm{Pb}, \mathrm{Zn}$ and $\mathrm{Sb}$. Most of them belong to the högbomite, crichtonite, spinel and hausmannite groups and to the pyrochlore supergroup. In some associations nežilovite plays an important role as a concentrator of $\mathrm{Pb}$ and $\mathrm{Zn}$. Dolomite associated to nežilovite (Fig. 3) is depleted in $\mathrm{Zn}$ (the content of $\mathrm{ZnO}$ is below $1 \mathrm{wt} . \%$ ). Braunite is present as an accessory component in the dolomite-nežilovite-phlogopite rock (Fig. 1) contains zinc and copper. A typical composition of braunite from this association is (wt.\%): $\mathrm{CaO} 0.78$, $\mathrm{MgO} 1.05, \mathrm{MnO} 5.77, \mathrm{ZnO} 2.25, \mathrm{CuO} 1.62, \mathrm{Al}_{2} \mathrm{O}_{3}$ $0.79, \mathrm{Mn}_{2} \mathrm{O}_{3} 67.54, \mathrm{Fe}_{2} \mathrm{O}_{3}$ 11.64, $\mathrm{SiO}_{2}$ 10.37, total $101.81\left(\right.$ the $\mathrm{Mn}^{2+}: \mathrm{Mn}^{3+}$ ratio is calculated by stoichiometry); the empirical formula is $\left(\mathrm{Mn}^{2+}{ }_{0.47} \mathrm{Zn}_{0.16}\right.$ $\left.\mathrm{Mg}_{0.15} \mathrm{Cu}_{0.12} \mathrm{Ca}_{0.08}\right)\left(\mathrm{Mn}^{3+}{ }_{5.04} \mathrm{Fe}^{3+}{ }_{0.87} \mathrm{Al}_{0.09}\right) \mathrm{Si}_{1.02} \mathrm{O}_{12}$.

Representative analyses of other accessory oxide minerals from metasomatic rocks of the Nežilovo orogenetic zone are given in Tables 2 to 4. Specific features of the majority of these minerals are high contents of $\mathrm{Zn}$ and/or Sb. In particular, $\mathrm{Sb}$ is the main high-valency charge-balancing component in some samples of zincohögbomite$2 N 6 S$ (analyses 2 and 3 in Table 2; Fig. 1), unlike initially described $\mathrm{Sb}$-, Ti- and Fe-deficient sample from the same locality $[15,21]$. Sb-rich zincohögbomite was found in the Nežilovo area by Jančev (2003). It is the first Sb-rich representative of the högbomite, nigerite and taaffeite groups including complex oxide minerals with structures consisting of alternating the spinel-type and the nolanite-type modules [21].

Rinmanite was first described as a mineral from the Garpenberg Norra $\mathrm{Zn}-\mathrm{Pb}$ mine, Hedemora, Dalarna, Sweden, with the idealized formula $\mathrm{Zn}_{2} \mathrm{Sb}_{2}\left(\mathrm{Mg}_{2} \mathrm{Fe}_{4}\right) \mathrm{O}_{14}(\mathrm{OH})_{2}$ and hexagonal unit cell $(a=5.9889(4), c=9.353(1)$, space group $P 6_{3} m c$ [22]). Rinmanite from Nežilovo (analysis 7 in Table 2) differs from type rinmanite in low content of $\mathrm{Mg}$ and high content of $\mathrm{Zn}$. Taking into account that $\mathrm{Mg}$ does not prevail in any structure sites of rinmanite (and, consequently, $\mathrm{Mg}$ is not a species-defining component in this mineral), the samples from Nežilovo represent a new chemical variety of rinmanite.

Almeidaite was discovered recently as a new mineral from Novo Horizonte, Bahia, Brazil [23, 24]. Samples from Nežilovo (analyses 1 and 2 in Table 3) represent the second find of this rare mineral belonging to the crichtonite group. In metasomatic rocks of the "Mixed series" complex almeidaite occurs in association with spessartine and zincohögbomite and forms anhedral grains at the contact of hematite with quartz (Fig. 4). 
T a ble 2

Representative compositional data for accessory oxide minerals from the Nežilovo orogenetic zone belonging to the högbomite, spinel and hausmannite groups, as well as rinmanite

\begin{tabular}{|c|c|c|c|c|c|c|c|}
\hline Mineral $\rightarrow$ & $\begin{array}{c}\text { Zincohög- } \\
\text { bomite- } \\
2 N 6 S \\
\end{array}$ & $\begin{array}{c}\text { Zincohög- } \\
\text { bomite- } \\
2 N 6 S \\
\end{array}$ & $\begin{array}{c}\text { Zincohög- } \\
\text { bomite- } \\
2 N 6 S\end{array}$ & $\begin{array}{c}\text { Franklinite } \\
\quad(?)^{1}\end{array}$ & Gahnite & Hetaerolite & Rinmanite \\
\hline \multirow[t]{2}{*}{ Constituent } & \multicolumn{7}{|c|}{ Wt.\% } \\
\hline & 1 & 2 & 3 & 4 & 5 & 6 & 7 \\
\hline $\mathrm{MgO}$ & 0.50 & bdl & 0.78 & bdl & bdl & bdl & 2.74 \\
\hline $\mathrm{MnO}$ & 0.31 & bdl & bdl & bdl & bdl & - & 0.58 \\
\hline $\mathrm{ZnO}$ & 40.07 & 40.45 & 35.31 & 36.78 & 44.58 & 32.12 & 27.37 \\
\hline $\mathrm{Al}_{2} \mathrm{O}_{3}$ & 44.46 & 43.38 & 43.56 & 5.13 & 53.39 & & 3.31 \\
\hline $\mathrm{Mn}_{2} \mathrm{O}_{3}$ & - & - & - & - & - & 64.95 & $\begin{array}{l}3.01 \\
-\end{array}$ \\
\hline $\mathrm{Fe}_{2} \mathrm{O}_{3}$ & 10.16 & 10.59 & 10.88 & 51.77 & 2.26 & 3.59 & 30.71 \\
\hline $\mathrm{TiO}_{2}$ & 2.39 & 1.30 & 1.05 & 1.49 & bdl & bdl & bdl \\
\hline $\mathrm{Sb}_{2} \mathrm{O}_{5}$ & 2.65 & 4.37 & 7.32 & 4.65 & bdl & bdl & 35.32 \\
\hline Total & 100.54 & 100.09 & 98.90 & 99.82 & 100.23 & 100.66 & $\begin{array}{c}53.02 \\
100.03\end{array}$ \\
\hline \multicolumn{8}{|c|}{ Formula coefficients } \\
\hline $\mathrm{Mg}$ & 0.18 & - & 0.30 & - & - & - & 0.63 \\
\hline $\mathrm{Mn}^{2+}$ & 0.06 & - & - & - & - & - & 0.08 \\
\hline $\mathrm{Zn}$ & 7.28 & 7.50 & 6.64 & 1.09 & 1.01 & 0.94 & 3.12 \\
\hline $\mathrm{Al}$ & 12.91 & 12.80 & 13.07 & 0.24 & 1.94 & & 0.61 \\
\hline $\mathrm{Mn}^{3+}$ & - & - & - & - & - & 1.95 & - \\
\hline $\mathrm{Fe}^{3+}$ & 1.88 & 2.00 & 2.08 & 1.56 & 0.05 & 0.11 & 3.56 \\
\hline $\mathrm{Ti}$ & 0.45 & 0.25 & 0.21 & 0.05 & - & - & - \\
\hline $\mathrm{Sb}^{5+}$ & 0.24 & 0.45 & 0.70 & 0.04 & - & - & 2.02 \\
\hline $\begin{array}{c}\text { Basis of } \\
\text { calculation }\end{array}$ & 23 cations & 23 cations & 23 cations & 3 cations & 3 cations & 3 cations & 10 cations \\
\hline
\end{tabular}

Note: ${ }^{1}$ Possibly this mineral is the $\mathrm{Fe}^{3+}$-analogue of zincohögbomite.

T a b l e 3

Representative compositional data for accessory crichtonite group minerals and nežilovite from the Nežilovo orogenetic zone

\begin{tabular}{|c|c|c|c|c|c|}
\hline Mineral $\rightarrow$ & Almeidaite & Almeidaite $^{1}$ & $\begin{array}{l}\text { Mn-deficient ana- } \\
\text { logue of almeidaite }\end{array}$ & Nežilovite & Nežilovite \\
\hline \multirow[t]{2}{*}{ Constituent } & \multicolumn{5}{|c|}{ Wt. $\%$} \\
\hline & 1 & 2 & 3 & 4 & 5 \\
\hline $\mathrm{CaO}$ & - & 0.24 & - & 0.38 & - \\
\hline $\mathrm{PbO}$ & 11.70 & 11.55 & 11.86 & 18.53 & 19.71 \\
\hline $\mathrm{UO}_{2}$ & 1.32 & 1.56 & - & - & - \\
\hline $\mathrm{MnO}$ & 2.43 & 2.52 & 1.27 & 16.42 & 14.09 \\
\hline $\mathrm{ZnO}$ & 7.40 & 7.87 & 8.23 & 14.67 & 13.99 \\
\hline $\mathrm{Al}_{2} \mathrm{O}_{3}$ & - & 0.28 & - & 6.69 & 5.83 \\
\hline $\mathrm{Fe}_{2} \mathrm{O}_{3}$ & 23.69 & 22.10 & 23.32 & 37.65 & 39.87 \\
\hline $\mathrm{TiO}_{2}$ & 49.86 & 48.42 & 49.50 & 4.24 & 3.75 \\
\hline $\mathrm{ZrO}_{2}$ & 0.68 & 0.89 & 1.73 & - & - \\
\hline $\mathrm{Sb}_{2} \mathrm{O}_{5}$ & 2.55 & 3.20 & 3.85 & 0.28 & 2.06 \\
\hline Total & 99.63 & 98.63 & 99.76 & 98.86 & 99.30 \\
\hline \multicolumn{6}{|c|}{ Formula coefficients } \\
\hline $\mathrm{Ca}$ & - & 0.09 & - & 0.08 & - \\
\hline $\mathrm{Pb}$ & 1.03 & 1.03 & 1.04 & 0.93 & 1.01 \\
\hline $\mathrm{U}^{4+}$ & 0.09 & 0.11 & - & - & - \\
\hline $\mathrm{Mn}^{2+}$ & 0.68 & 0.72 & 0.35 & 2.60 & 2.28 \\
\hline $\mathrm{Zn}$ & 1.78 & 1.94 & 1.98 & 2.02 & 1.97 \\
\hline $\mathrm{Al}$ & - & 0.11 & - & 1.47 & 1.31 \\
\hline $\mathrm{Fe}^{3+}$ & 5.83 & 5.55 & 5.74 & 5.29 & 5.73 \\
\hline $\mathrm{Ti}$ & 12.27 & 12.16 & 12.18 & 0.59 & 0.54 \\
\hline $\mathrm{Zr}$ & 0.10 & 0.15 & 0.29 & - & - \\
\hline $\mathrm{Sb}^{5+}$ & 0.34 & 0.39 & 0.46 & 0.02 & 0.15 \\
\hline $\begin{array}{c}\text { Basis of } \\
\text { calculation } \\
\end{array}$ & $\begin{array}{c}21 \text { cations } \\
\text { except } \mathrm{Pb} \text { and } \mathrm{U} \\
\end{array}$ & $\begin{array}{c}21 \text { cations } \\
\text { except } \mathrm{Pb}, \mathrm{Ca} \text { and } \mathrm{U} \\
\end{array}$ & $\begin{array}{l}21 \text { cations } \\
\text { except } \mathrm{Pb}\end{array}$ & 13 cations & 13 cations \\
\hline
\end{tabular}


Besides almeidaite s.s., its Mn-deficient analogue (or an analogue of senaite with $\mathrm{Fe}^{2+}$ substituting $\mathrm{Mn}^{2+}$ ) has been found in association with hydroxyplumboroméite, zincohögbomite- $2 N 6 S$, gahnite, hematite, barite, quartz, Zn-rich phlogopite and amphiboles (analysis 3 in Table 3).

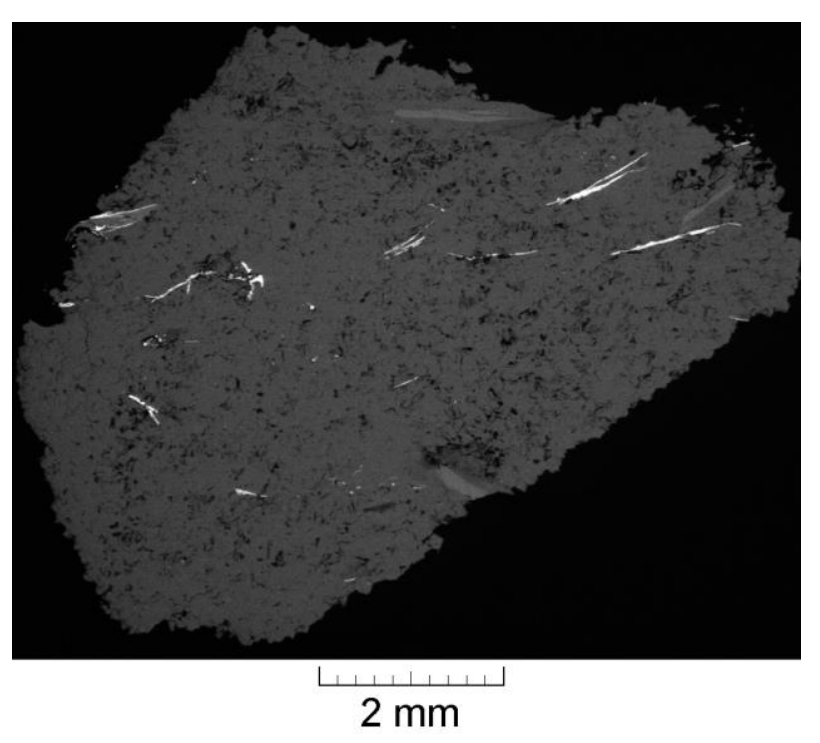

Fig. 3. Nežilovite (white lamellae), Zn-bearing phlogopite (light gray lamellae) and $\mathrm{Zn}, \mathrm{Cu}$-bearing braunite (small white grains) in dolomite aggregate. Polished section. BSE image.

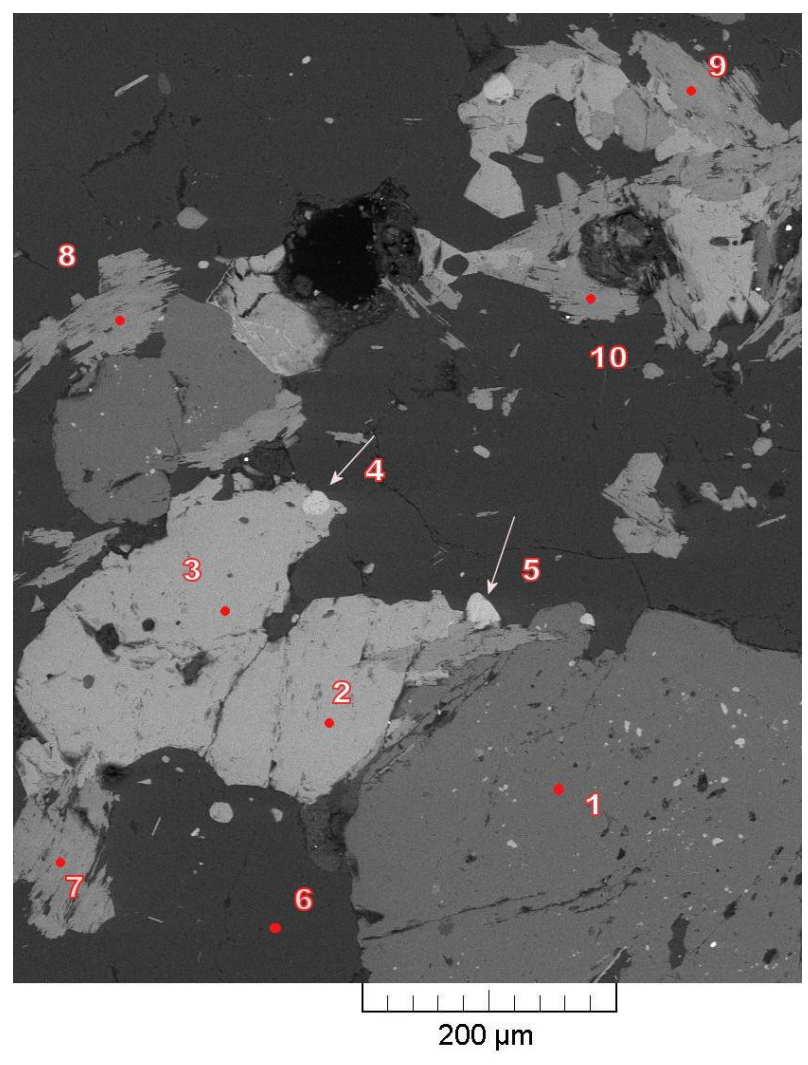

Fig. 4. Association of spessartine (1), hematite $(2,3)$, almeidaite $(4,5)$, quartz (6) and zincohögbomite (7-10). Polished section. BSE image.

Table 4

Representative compositional data for accessory pyrochlore-supergroup minerals from the Nežilovo orogenetic zone

\begin{tabular}{|c|c|c|c|c|c|}
\hline "Mineral $\rightarrow$ & $\begin{array}{c}\text { Hydroxyplumbo- } \\
\text { betafite }\end{array}$ & $\begin{array}{l}\begin{array}{l}\text { Hydroxyplumbo- } \\
\text { roméite }\end{array} \\
\end{array}$ & $\begin{array}{c}\text { Hydroxyplumbo- } \\
\text { roméite }\end{array}$ & $\begin{array}{c}\begin{array}{c}\text { Fluorcalcio- } \\
\text { roméite }\end{array} \\
\end{array}$ & $\begin{array}{l}\begin{array}{c}\text { Fluorcalcio- } \\
\text { roméite }\end{array} \\
\end{array}$ \\
\hline \multirow[t]{2}{*}{ Constituent } & \multicolumn{5}{|c|}{ Wt. $\%$} \\
\hline & 1 & 2 & 3 & 4 & 5 \\
\hline $\mathrm{Na}_{2} \mathrm{O}$ & bdl & bdl & bdl & 1.76 & 5.30 \\
\hline $\mathrm{CaO}$ & 3.82 & 3.88 & 7.17 & 13.11 & 17.10 \\
\hline $\mathrm{PbO}$ & 59.01 & 56.41 & 45.09 & 22.19 & bdl \\
\hline $\mathrm{Fe}_{2} \mathrm{O}_{3}$ & bdl & 0.90 & bdl & bdl & 1.53 \\
\hline $\mathrm{TiO}_{2}$ & 14.55 & 12.03 & 11.54 & 12.20 & bdl \\
\hline $\mathrm{Sb}_{2} \mathrm{O}_{5}$ & 22.93 & 25.40 & 34.89 & 47.55 & 75.43 \\
\hline $\mathrm{F}$ & bdl & bdl & bdl & 2.30 & 3.52 \\
\hline$-\mathrm{O}=\mathrm{F}_{2}$ & - & - & - & -0.97 & -1.48 \\
\hline Total & 100.31 & 100.57 & 98.67 & 100.77 & 101.40 \\
\hline \multicolumn{6}{|c|}{ Formula coefficients } \\
\hline $\mathrm{Na}$ & - & - & - & 0.25 & 0.70 \\
\hline $\mathrm{Ca}$ & 0.42 & 0.43 & 0.71 & 1.05 & 1.25 \\
\hline $\mathrm{Pb}$ & 1.63 & 1.59 & 1.12 & 0.44 & - \\
\hline $\mathrm{Fe}^{3+}$ & - & 0.07 & - & - & 0.08 \\
\hline $\mathrm{Ti}$ & 1.13 & 0.94 & 0.80 & 0.68 & - \\
\hline $\mathrm{Sb}^{5+}$ & 0.87 & 0.99 & 1.20 & 1.32 & 1.92 \\
\hline $\mathrm{F}$ & - & - & - & 0.54 & 0.76 \\
\hline $\begin{array}{c}\text { Basis of } \\
\text { calculation }\end{array}$ & $\begin{array}{c}2 \text { cations } \\
\mathrm{Sb}+\mathrm{Ti} \\
\end{array}$ & $\begin{array}{c}2 \text { cations } \\
\mathrm{Sb}+\mathrm{Ti}+\mathrm{Fe}^{3+} \\
\end{array}$ & $\begin{array}{c}2 \text { cations } \\
\mathrm{Sb}+\mathrm{Ti} \\
\end{array}$ & $\begin{array}{c}2 \text { cations } \\
\mathrm{Sb}+\mathrm{Ti} \\
\end{array}$ & $\begin{array}{l}2 \text { cations } \\
\mathrm{Sb}+\mathrm{Fe}^{3+} \\
\end{array}$ \\
\hline
\end{tabular}

Note: ${ }^{1}$ Additionally this sample contains 2.63 wt. $\% \mathrm{Ce}_{2} \mathrm{O}_{3}$ corresponding to 0.07 apfu Ce. 
Accessory pyrochlore-supergroup minerals (members of the roméite and, more rarely, the betafite groups) are very diverse in metasomatic rocks of the "Mixed series" complex (Table 4). They form yellow to brown-yellow octahedral crystals up to $0.1 \mathrm{~mm}$ and their aggregates. Compositional inhomogeneity is often observed within a single crystal, as zones more or less enriched in $\mathrm{Pb}, \mathrm{Sb}, \mathrm{Na}$ and $\mathrm{F}$ (Figs. 5, 6). Both inner and outer zones can be enriched in chalcophile elements: $\mathrm{Pb}$ and $\mathrm{Sb}$.

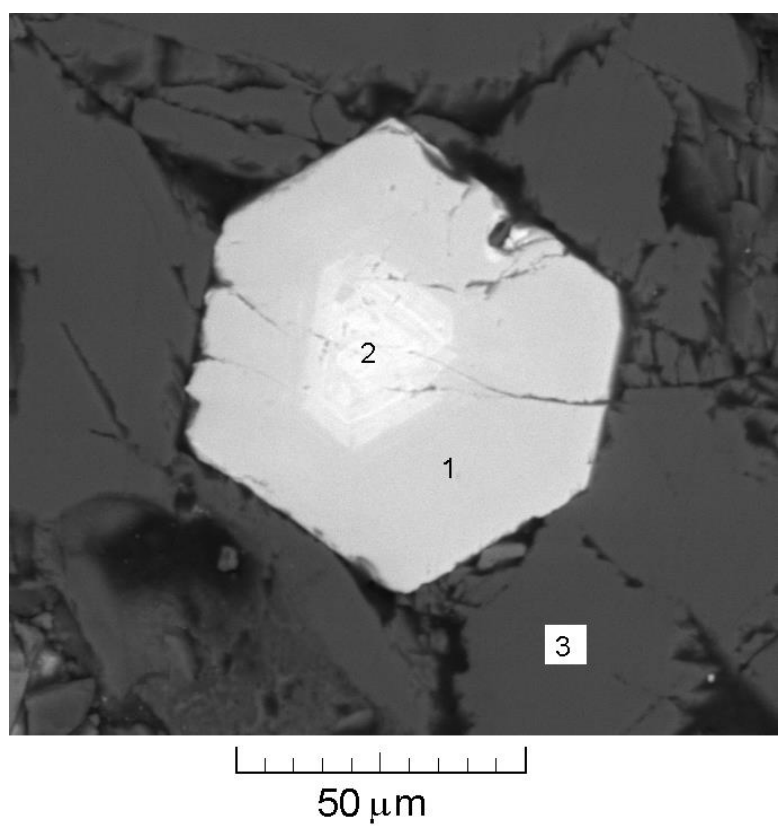

Fig. 5. Pb-poor (1) and Pb-rich (2) fluororoméite forming zones in a crystal embedded in the aggregate of $\mathrm{Zn}$-bearing amphibole. Polished section. BSE image.

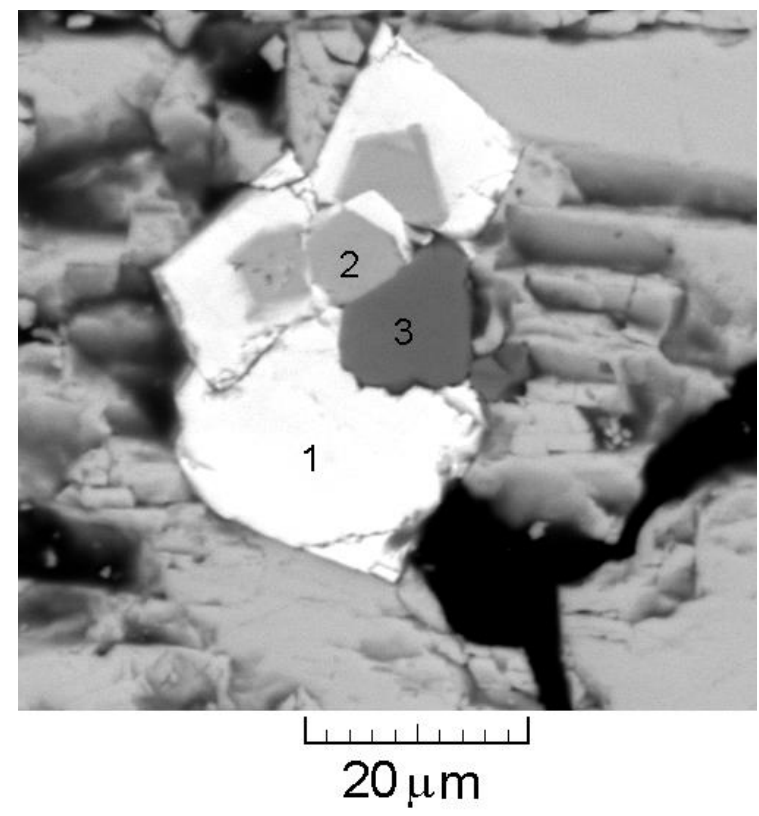

Fig. 6. Intergrowth of hydroxyplumbobetafite (1), fluororoméite (2) and hematite (3) in barite. Polished section. BSE image.
Hydroxyplumbobetafite (Fig. 6, analysis 1 in Table 4) is not approved by the Commission on New Minerals Nomenclature and Classification of the International Mineralogical Assosiation. Moreover, this mineral is not listed among pyrochloresupergroup species for which analytical evidence is deemed adequate [25]. Consequently, hydroxyplumbobetafite is a potentially new mineral species that needs further investigations.

Högbomite-group minerals are widespread in metasomatic rocks of the Nežilovo orogenetic zone [26]. They are characterized by very high contents of $\mathrm{Zn}$ and variable contents of $\mathrm{Sb}$. Both $\mathrm{Sb}$-rich and Sb-poor zincohögbomite-2N6S form yellow imperfect platy crystals (usually up to $0.1 \times 0.3 \times 0.3 \mathrm{~mm}$ ) in association with hydroxyplumboroméite, crichtonite-group minerals, gahnite, hematite, barite, quartz, Zn-rich phlogopite and amphiboles. Usually crystals of zincohögbomite$2 N 6 S$ are split to form aggregates of lamellar blocks sub-coplanar to the $a b$ plane and resembling open book in a cross section. The mineral was determined by us as zincohögbomite- $2 N 6 S$, but not as any other zincohögbomite species based on both electron probe and powder X-ray diffraction data (Table 5).

\section{Table 5}

\section{Powder X-ray diffraction data of Sb-rich zincohögbomite-2N6S from Nežilovo.}

\begin{tabular}{lll}
\hline \hline$I_{\text {obs }}$ & $d_{\text {obs }}(\AA)$ & $h k l^{*}$ \\
\hline 2 & 4.77 & 102 \\
1 & 4.34 & 104 \\
5 & 2.969 & 1.0 .10 \\
32 & 2.871 & 110 \\
15 & 2.776 & 1.0 .11 \\
1 & 2.640 & 1.0 .12 \\
15 & 2.472 & 201 \\
100 & 2.451 & $202,118,203$ \\
5 & 2.406 & 204 \\
1 & 2.321 & 1.0 .14 \\
3 & 2.306 & 206 \\
3 & 2.052 & 2.0 .10 \\
2 & 1.981 & 2.0 .11 \\
4 & 1.863 & $211,212,0.0 .20$ \\
4 & 1.672 & 2.1 .10 \\
10 & 1.659 & 1.0 .21 \\
6 & 1.645 & $300,2.1 .11,2.0 .17$ \\
3 & 1.585 & $306,1.0 .22,2.0 .18$ \\
30 & 1.566 & 2.1 .13 \\
28 & 1.559 & 308 \\
5 & 1.534 & $2.0 .19,1.0 .23,2.1 .14$ \\
37 & 1.436 & $2.0 .21,220,222$ \\
\hline \hline
\end{tabular}

* Indexes $h k l$ were chosen taking into account intensities of reflections in the XRD powder pattern calculated from the crystal structure data of zincohögbomite-2N6S (Armbruster et al., 1998). 
The hexagonal unit cell dimensions of our Sb-rich zincohögbomite-2N6S, calculated from these powder-diffraction data, are: $a=5.736(2), c$ $=36.98(2) \AA$ and $V=1054(1) \AA^{3}$, that is similar to the data for the structurally studied Sb-free zincohögbomite-2N6S, with the empirical formula $\mathrm{Zn}_{12.74}\left(\mathrm{Mg}_{0.43} \mathrm{Fe}_{2} \mathrm{Ti}_{1.56} \mathrm{Al}_{5.29}\right) \mathrm{Al}_{24} \mathrm{O}_{62}(\mathrm{OH})_{2}$, from Nežilovo reported in [15]: $a=5.729(2), c=37.097(5)$ $\AA$ and $V=1054.45 \AA^{3}$.

In some areas fine-grained rocks (with mean sizes of grains $c a .0 .05-0.1 \mathrm{~mm}$ ) enriched in franklinite are intersected by hydrothermal veinlets $1-2$ mm thick almost completely composed of a coronadite-group mineral. Its empirical formula is

$$
\left[\mathrm{Mn}^{4+}{ }_{6.00}\left(\mathrm{Fe}^{3+}{ }_{1.52} \mathrm{Pl}_{0.28} \mathrm{Mn}_{0.98}{ }^{3+}{ }_{0.17} \mathrm{Ba}_{0.40}{ }_{0.03}\right)\right]_{\Sigma 8.00} \mathrm{O}_{16.365} ;
$$

the strongest lines of the powder X-ray diffraction pattern $[d, \AA(I, \%)]$ are: 3.47 (60), 3.10 (100), 2.43 (90), 2.204 (15), 2.174 (10). This mineral needs further investigations. According to the approved nomenclature of the hollandite supergroup (IMA 11-F; see [27]), is should be named ferricoronadite.

\subsection{Arsenates}

The most common arsenic-bearing minerals in metasomatic rocks related to the "Mixed series" are arsenates (mainly, tilasite and hedyphane [6,7, 14]; Table 6).

Table 6
Tilasite was discovered in dolomitic marbles in forms of veinlets characterized with a very complex mineral paragenesis composed of barite, tilasite, $\mathrm{Zn}$-rich aegirine-augite, $\mathrm{Zn}$-rich richterite, $\mathrm{Zn}$-rich magnesioriebeckite, $\mathrm{Zn}$-rich phlogopite, $\mathrm{Pb}$ bearing piemontite, gahnite, quartz, dolomite, roméite-group minerals, hetaerolite, etc. On the hydrothermal stage, the older rocks containing finegrained gahnite, $\mathrm{Zn}$-rich aegirine-augite and $\mathrm{Zn}$-rich amphiboles were metasomaticaly replaced with the younger coarse-grained rock enriched in barite and/or dolomite and containing tilasite. Accessory tilasite and As-bearing fluorapatite (analyses 1, 4, 5 in Table 6) occur in barite schists in association with barite, Zn-rich amphiboles, Zn-rich rinmanite, gahnite, franklinite, hetaerolite, braunite, etc.

Grains of the minerals belonging to the mimetite-hedyphane solid-solution series are disseminated in polymictic aggregates (composed of hedyphane, quartz, barite, albite and biotite) forming veinlets up to $3-5 \mathrm{~mm}$ thick in dolomitic finegrained marbles. Accessory mimetite and hedyphane (analyses 2 and 3 in Table 6) occur in metasomatites in association with barite, $\mathrm{Zn}$-rich amphiboles, Zn-rich phlogopite, As-bearing fluorapatite, zincohögbomite- $2 N 6 S$, etc. It is remarkable that As-bearing fluorapatite associated with mimetite does not contain $\mathrm{Cl}$.

\begin{tabular}{|c|c|c|c|c|c|}
\hline Mineral $\rightarrow$ & Tilasite & Mimetite & Hedyphane $^{1}$ & $\begin{array}{l}\text { As-bearing } \\
\text { fluorapatite }\end{array}$ & $\begin{array}{l}\text { As-bearing } \\
\text { fluorapatite }\end{array}$ \\
\hline \multirow[t]{2}{*}{ Constituent } & \multicolumn{5}{|c|}{ Wt.\% } \\
\hline & 1 & 2 & 3 & 4 & 5 \\
\hline $\mathrm{CaO}$ & 23.67 & 3.54 & 5.20 & 49.73 & 53.01 \\
\hline $\mathrm{PbO}$ & bdl & 68.35 & 66.72 & bdl & bdl \\
\hline $\mathrm{MgO}$ & 18.68 & bdl & bdl & bdl & bdl \\
\hline $\mathrm{MnO}$ & 0.96 & bdl & bdl & 0.59 & bdl \\
\hline $\mathrm{P}_{2} \mathrm{O}_{5}$ & 1.14 & bdl & bdl & 32.65 & 38.45 \\
\hline $\mathrm{As}_{2} \mathrm{O}_{5}$ & 50.93 & 25.46 & 25.04 & 14.29 & 6.74 \\
\hline $\mathrm{F}$ & 6.96 & bdl & bdl & 3.00 & 3.77 \\
\hline $\mathrm{Cl}$ & bdl & 2.60 & 2.78 & bdl & bdl \\
\hline$-\mathrm{O}=(\mathrm{F}, \mathrm{Cl})_{2}$ & -2.93 & -0.59 & -0.63 & -1.26 & -1.59 \\
\hline Total & 99.41 & 99.36 & 101.09 & 99.00 & 100.38 \\
\hline \multicolumn{6}{|c|}{ Formula coefficients } \\
\hline $\mathrm{Ca}$ & 0.95 & 0.85 & 1.15 & 4.55 & 5.01 \\
\hline $\mathrm{Pb}$ & - & 4.15 & 3.72 & - & - \\
\hline $\mathrm{Mg}$ & 1.04 & - & - & - & - \\
\hline $\mathrm{Mn}$ & 0.03 & - & - & 0.04 & - \\
\hline $\mathrm{P}$ & 0.04 & - & - & 2.36 & 2.71 \\
\hline As & 0.99 & 3.00 & 2.71 & 0.64 & 0.29 \\
\hline $\mathrm{F}$ & 0.82 & - & - & 0.81 & 0.99 \\
\hline $\mathrm{Cl}$ & bdl & 0.99 & 0.98 & - & - \\
\hline
\end{tabular}

Representative compositional data for As-bearing accessory minerals from the Nežilovo orogenetic zone

\begin{tabular}{llllll}
\hline Basis of calculation & 5 anions & 3 atoms $\mathrm{As}$ & 3 atoms $\mathrm{As}+\mathrm{V}+\mathrm{Fe}$ & 3 atoms $\mathrm{P}+\mathrm{As}$ & 3 atoms P+As \\
\hline \hline Note: ${ }^{1}$ Additionally this sample contains & 1.06 wt. $\% \mathrm{Fe}_{2} \mathrm{O}_{3}$ and 0.92 wt. $\% \mathrm{~V}_{2} \mathrm{O}_{5}$ corresponding to 0.16 apfu $\mathrm{Fe}^{3+}$ and 0.13 apfu $\mathrm{V}^{5+}$
\end{tabular}




\section{DISCUSSION}

Post-magmatic fluids related to metarhyolites are considered as a possible source of a number of specific, ore and rare elements $(\mathrm{Pb}, \mathrm{Zn}$, $\mathrm{Sb}, \mathrm{As}, \mathrm{Cu}, \mathrm{Ba}, \mathrm{REE}$, etc.) in contact-metasomatic rocks widespread in the Nežilovo area [10]. On the earliest stages of the formation of these rocks, high-temperature pneumatolytic processes occurred at conditions of a very high oxygen fugacity. Accessory $\mathrm{Zn}, \mathrm{Fe}, \mathrm{Mn}, \mathrm{Cr}$-spinels, Zn-bearing pyroxene and garnets are the indicators of the earliest stages of metasomatism. $\mathrm{Zn}, \mathrm{Fe}, \mathrm{Mn}$-spinels of the second generation, nežilovite, zincohögbomite (including its Sb-bearing variety or analogue), $\mathrm{Zn}$ rich rinmanite, epidote- $(\mathrm{Pb})$, piemontite- $(\mathrm{Pb})$, hematite, almeidaite, etc., crystallized on the second stage. During the lowest temperature hydrothermal processes, different coarse-grained and fine-grained rocks enriched in barite, carbonates, quartz and albite and containing accessory arsenates were formed. Hydrothermal sphalerite-galena mineralization is of minor importance and is confined to local zones with minerals formed under low oxygen fugacity.

As it is noted above, specific features of metasomatic rocks from the orogenetic zone related to the "Mixed series" of Nežilovo are high contents of chalcophile elements $(\mathrm{S}, \mathrm{As}, \mathrm{Sb}, \mathrm{Zn}, \mathrm{Pb})$ concentrated mainly in oxides and oxysalts, whereas sulfides and sulfosalts are present only in trace amounts. The oxidized ores form lens-shaped bodies at the contact of meta-quartz porfiry and banded microcline schists. Hypothetically, their formation is connected with fluids derived not only from the meta-rhyolites, but also from a deep seated magmatic chamber. This assumption is based on the fact that the magmatic body of the mentioned rhyolites is very small $(c a .1 .0 \times 0.8 \times 0.1 \mathrm{~km})$, with a very limited capacity to contribute very complex and widespread mineral parageneses enriched in chalcophile elements.

Based on the regional geological investigations carried out in the time period from 1955 to 1960, the "Mixed series" is a transgressive series formed as a result of a very complex polymetamorphic transformation of marine sediments. Numerous available isotopic ${ }^{32} \mathrm{~S} /{ }^{34} \mathrm{~S}$ data for barite show that $S$ could be of marine origin. The very complex mineral parageneses of higher temperature stages are often metasomatically replaced with hydrothermal mineral assemblages in which barite quantitatively predominates over all other minerals showing very high barium potential. The presence of cymrite in the rocks underlying dolomitic marbles also indicates a high activity of barium and moderate $\left(250-300{ }^{\circ} \mathrm{C}\right)$ temperatures of crystallization (see [28]). As a result, almost all sulfur becomes fixed in barite that is characterized by a very low solubility and mobility under hydrother- mal conditions up to $300{ }^{\circ} \mathrm{C}$ and 1400 bars [29]. Another possible factor promoting the crystallization of chalcophile elements in the form of oxygenbearing minerals is caused by high Eh values.

Although the mineral parageneses from the Nežilovo area cannot be compared with anyone in the world, they show some similarities with the well-known Franklin and Sterling Hill zinc deposits in New Jersey, USA. According to W.A. Tarr [30], these deposits were formed as a result of oxidation of initial ore bodies. In the course of these processes sphalerite oxidized, in greater or less degree, to smithsonite or hemimorphite or, rarely, to willemite. The iron sulfide (or sulfides) was oxidized to form hematite or limonite. The rhodochrosite was probably oxidized, in part at least, to manganite, pyrolusite, and braunite. On the next step, the ore bodies have been deeply buried and intensely metamorphosed by heat and pressure. All the minerals in the original rock have been recrystallized. Locally, they are coarsely crystalline aggregates [30].

The famous Långban in Sweden is another example of an endogenic ore deposit containing chalcophile elements solely in form of oxygenbearing minerals. Some aspects of the origin of this deposit have been discussed by B. Bollmark [31]. Based on chemical analyses of drillcore samples and ${ }^{85} \mathrm{Sr}:{ }^{86} \mathrm{Sr}$ ratios, he concluded that the formation of an ore progenitor sequence was initiated by the exhalation of iron- and manganese-rich solutions of deep-seated origin and possibly of latestage differentiation. The exhalation presumably took place in aerated sea water, where oxidation occurred. By analogy with the formation of recent hydrothermal submarine Fe-Mn deposits, it could be assumed that $\mathrm{P}, \mathrm{V}, \mathrm{Cu}, \mathrm{As}, \mathrm{Ba}, \mathrm{Pb}$, etc., were supplied by exhalations [31].

Acknowledgements. This work was financially supported by the Russian Foundation for Basic Research (grant no. 14-05-00276-a). We thank Maria G. Krzhizhanovskaya for her help in the powder X-ray study of zincohögbomite-2N6S. The support by the SPbSU X-Ray Diffraction Resource Center in the XRD powder-diffraction studies is acknowledged.

\section{REFERENCES}

[1] Lj. Barić, T. Ivanov, Mineralvergesellschaftung in der Umgebung des Dorfes Nežilovo am Jakupica-Gebirge in Mazedonien, Bull. Sci., Zagreb, 5, 2 (1960).

[2] T. Ivanov, S. Jancev, "Nežilovo" - A complex polymetallic deposit of "Franklin Furnace" type in Macedonia. Proceedings of the Yugoslavian Geological Congress 5, Ljubljana, 1976, pp. 69-78.

[3] S. Jančev, Ore occurrence of cymrite at the village of Nežilovo in Macedonia, Bulletin Scientifique, Section A: Sciences Naturelles, Techniques et Medicales, Zagreb, 20, 9-10 (1975).

[4] S. Jančev, Ba-rich and Zn-rich silicate minerals, Sb-rich gahnite and braunite from the ore occurrences in the mixed 
series of the Pelagonian massif at the village of Nežilovo in Macedonia, Geologia Macedonica. 8(1), 39-44 (1994).

[5] Lj. Barić, Piemontit, Gahnit und Rutil aus dem Fundort der Blei und Zinkerze bei dem Dorfe Nežilovo in Mazedonien, Glasnik Prirodnjačkogo muzeja u Beogradu, Serija A, Geološke nauke, 13, 200-204 (1960).

[6] S. Jančev, Preliminary results of mineralogical investigations of tilasite, $\mathrm{CaMg}\left(\mathrm{AsO}_{4}\right) \mathrm{F}$, from a show of ore no. 9 in barite schists from the „Mixed series“ outcropping at the Babuna river, Macedonia, Tehnika Rudarstvo-GeologijaMetalurgija, XXXII(9), 1273-1274 (1981) (in Serbian).

[7] S. Jančev, A mineral of hedyphane $(\mathrm{Pb}, \mathrm{Ca})_{5}\left(\mathrm{AsO}_{4}\right)_{3} \mathrm{Cl}$ structure from the "Mixed series“ in the upper part of the Babuna river, Macedonia, Geologica Macedonica, I(1), 57-61 (1984).

[8] S. Jančev, Pb-piemontite from a show of ore in the Mixed series outcropping near the Babuna river, Macedonia, Proceedings of XII Congress on the Geology of Yugoslavia, Ohrid, Macedonia, II: Mineralogija $i$ Petrologija, 1990, pp. 62-66 (in Macedonian).

[9] S. Jančev, $\mathrm{Pb}$-epidote - hancockite and $\mathrm{Zn}$-rich pyroxenes from the ore occurrences in the mixed series in the upper part of the Babuna river, Macedonia, Proceedings of the Symposium of Plate Tectonic Aspects of Alpine Metallogeny in the Carpatho-Balkan Region, 1997, pp. 143-145.

[10] S. Jančev, Zn-rich pyroxenes from the occurrences in the mixed series in the upper part of the Babuna river, Macedonia, Geologija (Ljubljana), 40, 283-289 (1997).

[11] S. Jančev, Peculiar antimony-bearing minerals of the spinel group from the metamorphic rocks near Nežilovo village, Macedonia, Geochemistry, Mineralogy and Petrology (Sofia, Bulgaria), 38, 73-78 (2001).

[12] V. Bermanec, T. Armbruster, R. Oberhänsli, V. Zebec, Crystal chemistry of $\mathrm{Pb}$ - and $R E E$-rich piemontite from Nežilovo, Macedonia, Schweiz. Mineral. Petrogr. Mitt. 74, 321-328 (1994).

[13] V. Bermanec, D. Holtstam, D. Sturman, A. Criddle, M. Back, S. Śćavničar, Nežilovite, a new member of the magnetoplumbite group, and the crystal chemistry of magnetoplumbite and hibonite, Can. Mineral, 34, 12871297 (1997).

[14] S. Jančev, V. Bermanec, Solid solution between epidote and hancockite from Nežilovo, Macedonia, Geologia Croatica, 51(1), 23-26 (1998).

[15] T. Armbruster, V. Bermanec, V. Zebec, R. Oberhänsli, Titanium and iron poor zincohogbomite- $16 \mathrm{H}, \mathrm{Zn}_{14}\left(\mathrm{Al}, \mathrm{Fe}^{3+}\right.$, Ti,Mg $)_{8} \mathrm{Al}_{24} \mathrm{O}_{62}(\mathrm{OH})_{2}$, from Nežilovo, Macedonia: Occurrence and crystal structure of a new polysome, Schweiz. Mineral. Petr. Mitt.,78(3), 469-477 (1998).

[16] S. Jančev, N. V. Chukanov, Short review of some rare minerals from "Mixed series" in the pre-Cambrian complex near Nežilovo village, Macedonia, Proceedings of the First Congress of Geologists of Republic Macedonia, Ochrid, 2008, pp. 10-12.

[17] N. V. Chukanov, D. A. Varlamov, F. Nestola, D. I Belakovskiy, J. Goettlicher, S. N. Britvin, A. Lanza, S. Jančev, Piemontite-( $\mathrm{Pb}), \quad \mathrm{CaPbAl}_{2} \mathrm{Mn}^{3+}\left[\mathrm{Si}_{2} \mathrm{O}_{7}\right]\left[\mathrm{SiO}_{4}\right]$ $\mathrm{O}(\mathrm{OH})$, a new mineral species of the epidote supergroup, Neues Jahrbuch für Mineralogie - Abhandlungen. 189(3), 275-286 (2012).
[18] N. V. Chukanov, Infrared spectra of mineral species: Extended library, Springer-Verlag GmbH, DordrechtHeidelberg-New York-London, 2014, 1716 pp.

[19] C. Klein, J. Ito: Zincian and manganoan amphiboles from Franklin, New Jersey, The American Mineralogist, 53, 1264-1275 (1968)

[20] M. Marks, R. Halama, T. Wenzel, G. Markl G., Trace element variations in clinopyroxene and amphibole from alkaline to peralkaline syenites and granites: implications for mineral-melt trace-element partitioning, Chemical Geology, 211, 185-215 (2004).

[21] T. Armbruster, Revised nomenclature of högbomite, nigerite, and taaffeite minerals, European Journal of Mineralogy, 14, 389-395 (2002).

[22] D. Holstam, K. Gatedal, K. Södersberg, R. Norrestam, Rinmanite, $\mathrm{Zn}_{2} \mathrm{Sb}_{2} \mathrm{Mg}_{2} \mathrm{Fe}_{4} \mathrm{O}_{14}(\mathrm{OH})_{2}$, a new mineral species with a nolanite-type structure from the Garpenberg Norra mine, Dalarna, Sweden, The Canadian Mineralogist, 39, 1675-1683 (2001).

[23] L. A. D. Menezes Filho, N. V. Chukanov, R. K. Rastsvetaeva, S. M. Aksenov, I. V. Pekov, M. L. S. C. Chaves, R. Scholz, D. Atencio, P. R. G. Brandão, A Romano, L. C. A. de Oliveira, J. D. Ardisson, K. Krambrock, R. L. Moreira, F. S. Guimarães, A. C. Persiano, R. P. Richards, Almeidaite, $\mathrm{PbZn}_{2}(\mathrm{Mn}, \mathrm{Y})\left(\mathrm{Ti}, \mathrm{Fe}^{3+}\right)_{18} \mathrm{O}_{37}(\mathrm{OH}, \mathrm{O})$ a new crichtonite-group mineral, from Novo Horizonte, Bahia, Brazil. Mineralogical Magazine (2014) (in press).

[24] R. K. Rastsvetaeva, S. M. Aksenov, N. V. Chukanov, L. A. Menezes, Crystal structure of almeidaite, a new mineral of the crichtonite group, Doklady Chemistry, 455(12), 53-57 (2014)

[25] D. Atencio, M. B. Andrade, A. G. Christy, R. Gieré, P. M Kartashov, The pyrochlore supergroup of minerals: nomenclature, The Canadian Mineralogist, 48, 673-698 (2010).

[26] S. Jančev, Sb-bearing minerals of the högbomite group from the ore occurrences near Nežilovo village, Macedonia, Geologica Macedonica, 17, 59-64 (2003).

[27] C. Biagioni, C. Capalbo, M. Pasero, Nomenclature tunings in the hollandite supergroup. European Journal of Mineralogy, 25, 85-90 (2013).

[28] N. V. Sorokhtina, N. V. Chukanov, A. V. Voloshin, Ya. A. Pakhomovsky, A. N. Bogdanov, M. M. Moiseev, Cymrite as an indicator of high barium activity in the formation of hydrothermal rocks related to carbonatites of the Kola Peninsula, Geology of Ore Deposits, 50(7), 620-628 (2008).

[29] C. W. Blount, Barite solubilities and thermodynamic quantities up to $300{ }^{\circ} \mathrm{C}$ and 1400 bars, The American Mineralogist, 62, 942-957 (1977).

[30] W. A. Tarr, The origin of the zinc deposits at Franklin and Sterling Hill, New Jersey, The American Mineralogist, 14, 207-221 (1929).

[31] B. Bollmark, Some aspects of the origin of the deposit, in: Långban: The mines, their minerals, geology and explorers, D. Holstam, J. Langhof (Eds.), Raster Förlag, Stockholm, 1999, pp. 43-50. 